\title{
Levels of multiple supplements or nitrogen salt for beef heifers in pasture during the dry season ${ }^{1}$
}

\section{Ériton Egidio Lisboa Valente ${ }^{2}$, Mário Fonseca Paulino ${ }^{3}$, Edenio Detmann ${ }^{3}$, Sebastião de Campos Valadares Filho ${ }^{3}$, Lívia Vieira de Barros ${ }^{2}$, Tiago Sabella Acedo ${ }^{4}$, Victor Rezende Moreira Couto ${ }^{2}$, Sidnei Antonio Lopes ${ }^{2}$}

\author{
1 Projeto financiado pela Fapemig e pelo CNPq \\ 2 Programa de Pós-graduação em Zootecnia - Universidade Federal de Viçosa. \\ ${ }^{3}$ Departametno de Zootecnia, Universidade Federal de Viçosa. Pesquisador INCT-CA. \\ 4 Pesquisqador Tortuga Cia. Zootécnica Agrária.
}

\begin{abstract}
The study assessed performance, microbial protein synthesis, intake and digestibility of nutrients by beef heifers receiving levels of multiple supplements or nitrogen salt, in a self-controlled intake, on pasture, during the dry season. Thirty-five beef heifers, from 6 to 9 months of age and average initial body weight of $203.4 \pm 4.5 \mathrm{~kg}$, were used. Study factors were: control - mineral mixture; nitrogen salt $-50 \%$ of urea + mineral mixture, at proportion of $1: 1$, and $50 \%$ of corn (75\% of crude protein); levels of multiple supplementation - multiple supplements with different percentages of intake controller mixture (urea + mineral mixture, at the proportion of 1:1), corn and soybean meal (45\% of crude protein). Supplement consumptions observed were: 115, 173, 572 and 1214 g/animal/day for animals fed on nitrogen salt, low, medium and high levels of multiple supplement, respectively. Supplemented animals had greater average daily gain, evidencing the positive linear effect of the levels of multiple supplementation on average daily gain. Overall, there were no significant differences between average daily gain of animals fed on multiple supplements or nitrogen salt. Supplementation increased the intake and digestibility of nutrients, except for digestibility of neutral detergent fiber, although the intake of digested neutral detergent fiber increased. Supplementation increased the production of microbial nitrogen as well as nitrogen losses in urine, although the quantity of nitrogen assimilated by bacteria, proportionally to intake, was higher. Supplementation improves nutritional parameters and weight gain.
\end{abstract}

Key Words: digestibility, intake, performance, self-control

\section{Introduction}

Positive interactive effects were observed with the addition of nitrogen and negative aspects with the addition of carbohydrates on consumption and digestibility in cattle fed low quality forage (Souza et al., 2010). However, supplementation jointed with nitrogenous compounds and carbohydrates broadened assimilation of nitrogen in the rumen environment. Thus, supplementation during dry season must prioritize supply of nitrogen compounds with a source of fast-degradation carbohydrates.

The level of multiple supplements that should be used depends on the desired intensification of the production systems. Larger quantities of multiple supplements enable higher weight gains (Paulino et al., 2008), but they can reduce pasture intake by the substitution effect (El-Shazli et al., 1961). The ideal amount of concentrate to be used in a system of cattle production is highly variable and depends on many factors, especially the price of the supplement (Figueiredo et al., 2007).
Supplements of self-controlled intake are an alternative to reduce spending on manpower, and they can be provided at intervals of days and the animals themselves regulate the consumption, consuming supplement daily. The animal does not become addicted to the supplement and it presents positive aspects in the nutritional point of view (Paulino et al., 2001).

Thus, the objective of this study was to evaluate performance, microbial protein production, intake and digestibility of nutrients ingested by beef heifers receiving levels of multiple supplementation or nitrogen salt, in self-control intake, on pasture, during the dry season.

\section{Material and Methods}

The experiment was conducted in the dry season, between July and October, 2008. The climate data from experimental period are represented in Figure 1. The evaluation period was of 84 days (three sub-periods of 28 days). 
Thirty-five heifers, Nellore or crossbred (Nelore $x$ Holstein), from 7 to 9 months of age and initial body weight of $203.4+4.5 \mathrm{~kg}$, were used. Study factors were: control mineral mixture, ad libitum; nitrogen salt - supplement with $50 \%$ urea + mineral mix $(47 \% \mathrm{NaCl})$ at $1: 1$ relation, and $50 \%$ ground corn grain, used only as an intake stimulator (75\% CP); levels of multiple supplementation - quantities of multiple, using different percentages of intake controller mixture [urea + mineral mixture $(47 \% \mathrm{NaCl})$ in a $1: 1$ relation], corn grain ground and soybean meal (45\% CP) (Table 1). Supplements were formulated so that the animals themselves controlled the intake of supplement, getting increasing amounts, considering linear effect of urea on the intake control.

An experimental area consisting of five 2.0 ha paddocks, with Brachiaria decumbens was used. In order to minimize possible effects of plots on experimental treatments, animals were rotated among the five pasture plots every $7 \mathrm{~d}$, allowing each group to stay the same period of time in each plot. Animals were weighed at the beginning of the experiment, after 14 days of adaptation to local and to the diet, and in the end of the experiment.

On the $14^{\text {th }}$ day of each subperiod, random pasture collections were made by cutting the forage at ground level in four $0.5 \times 0.5 \mathrm{~m}$ areas within each paddock to assessments of availabilities of total dry matter (TDM) and potentially digestible dry matter (PDDM).

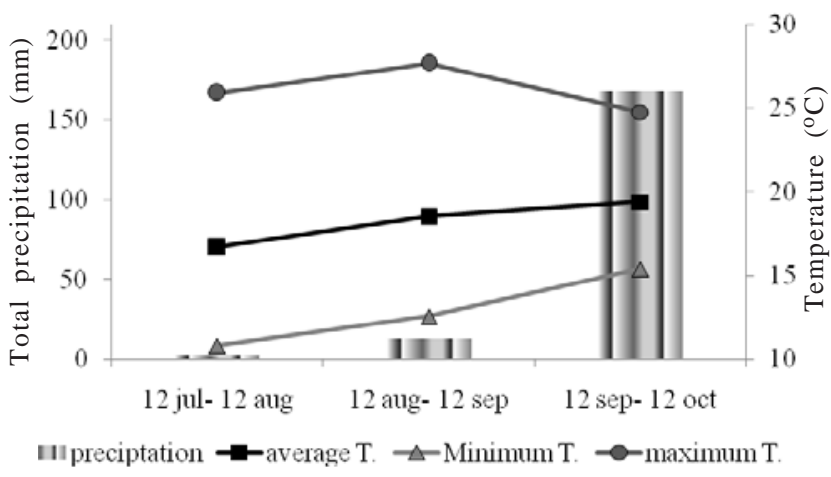

Figure 1 - Total precipitation, average temperature, average minimum temperature and average maximum temperature.
To evaluate the chemical composition of forage consumed by animals, manual simulations of grazing were performed on the first, $14^{\text {th }}$ and $28^{\text {th }}$ day of each experimental subperiod. After, a composed sample per experimental period was taken.

The ingredients of the supplements and pasture samples were dried in a forced ventilation oven $\left(60^{\circ} \mathrm{C} / 72\right.$ hours) and processed in a knife mill $(1 \mathrm{~mm})$. Afterwards, they were analyzed for dry matter (DM), total nitrogen $(\mathrm{N})$, insoluble neutral detergent nitrogen (INDN), acid detergent insoluble nitrogen (ADIN), lignin $\left(\mathrm{H}_{2} \mathrm{SO}_{4}, 72 \% \mathrm{w} / \mathrm{w}\right)$, ash and ether extract (EE), according to Silva \& Queiroz (2002); NDF, according to Mertens (2002), corrected for ash and protein; acid detergent fiber (ADF), according to Van Soest \& Robertson (1985), corrected for ash and protein; iNDF, obtained after incubation of Ankon ${ }^{\circledR}$ bags (F57) in situ for 240 hours, according to Casali et al. (2008); and non-protein nitrogen (NPN), according to description of Licitra et al. (1996). Soluble protein fraction (A + B1), and B2, B3 and C fractions of DM(Malafaia \& Vieira, 1997) were also determined. Organic matter (OM) was estimated by OM(\%) = 100 - \% ash . Non-fiber carbohydrate content, corrected for ash and protein (NFCap), was calculated as the following equation: NFCap $=100-[(\% C P-\% C P$ from urea $+\%$ of urea $)+\%$ NDFap + \%EE + \%ash] (Detmann \& Valadares Filho, 2010). Sample of availability of total dry matter was analyzed for DM, ash, NDF and iNDF as previously described.

PDDM was estimated according to the following equation (Paulino et al., 2006): PDDM $=0.98 \times(100-\mathrm{NDF})$ + (NDF - NDFi), in which: NDF = neutral detergent fiber (\%); iNDF = indigestible NDF (\%); PDDM = potentially digestible dry matter (\%); 0.98 = digestibility of intracellular content.

A trial with 9-day duration was conducted for evaluation of the nutritional parameters, in order to determine the intake and digestibility of ingested nutrients, as well as microbial protein production. The same 35 heifers were used in performance, in the same experimental area on the $38^{\text {th }}$ and $46^{\text {th }}$ days of the experimental period.

To estimate individual supplement intake, an external marker of titanium dioxide $\left(\mathrm{TiO}_{2}\right)$, equivalent to $10 \mathrm{~g}$ per

Table 1 - Percentage composition of the supplements based on natural matter

\begin{tabular}{lccccc}
\hline & \multicolumn{3}{c}{ Supplementation level } \\
\cline { 2 - 6 } & Control & Nitrogen salt & Low & Intermediate \\
\hline Corn grain ground & - & 50.00 & 73.50 & 40.60 & 30.80 \\
Soybean meal & - & - & - & 46.15 & 60.36 \\
Calcium carbonate & - & 25.00 & 1.50 & 0.75 & 6.25 \\
Urea & - & 25.00 & 12.50 & 6.25 \\
Mineral mixture & 100 & & & 12.50 & 4.17 \\
\hline
\end{tabular}

${ }^{1}$ Percentage composition: calcium - 8.7\%; phosphorus - 6.5\%; sulfur - 9.0\%; sodium - 18.7\%; zinc - $2400.00 \mathrm{mg} / \mathrm{kg}$; copper - 800.00 mg/kg; manganese - 1600.00 mg/kg; iodine $-40.00 \mathrm{mg} / \mathrm{kg}$; cobalt $-8.00 \mathrm{mg} / \mathrm{kg}$; selenium $-8.16 \mathrm{mg} / \mathrm{kg}$; chromium $-16.60 \mathrm{mg} / \mathrm{kg}$. 
animal per day, mixed in the supplement and distributed in the group of animals was used. To estimate fecal excretion, external marker chromic oxide $\left(\mathrm{Cr}_{2} \mathrm{O}_{3}\right)$ wrapped in cartridge paper was given to the animals, corresponding to $10 \mathrm{~g}$ per animal per day, and applied with the help of a metal probe, through the esophagus, always at 11 p.m.

From the nine days of the trial, six days were for adaptation of animals to $\mathrm{TiO}_{2}$ and to $\mathrm{Cr}_{2} \mathrm{O}_{3}$. On the last three days, fecal collections were performed at different times, 3 p.m., 11 a.m. and 7 a.m., each on a different day. On the fifth day of the trial, for evaluation of the nutritional parameters, a manual grazing simulation was done in each paddock separately, and this sample was used in the quantification of intake and digestibility.

Fecal samples were collected immediately after defecation or directly from the rectum of the animals, in quantities of approximately $300 \mathrm{~g}$. Samples were then dried in a forced air circulation oven $\left(60^{\circ} \mathrm{C}\right.$ for 72 hours). Afterwards, they were milled $(1 \mathrm{~mm})$. A compound fecal sample per animal was elaborated, from the three collection days. Samples were analyzed for concentrations of $\mathrm{Cr}$ in an atomic absorption spectrophotometer, as described by Williams et al. (1962); Ti was analyzed by colorimetry (Short et al., 1996), DM, N, EE, NDFap, iNDF and ash were analyzed as previously described.

Excretion of fecal dry matter was estimated based on the ratio between the amount of the indicator provided $\left(\mathrm{Cr}_{2} \mathrm{O}_{3}\right)$ and its concentration in feces.

The estimation of individual intake of supplement was obtained by using the external marker $\mathrm{TiO}_{2}$ through the following equation: $\mathrm{DMSI}=(\mathrm{FE} \times \mathrm{MCF}) / \mathrm{MCS}$, in which DMSI = dry matter supplement intake (kg/day); FE = fecal excretion $(\mathrm{kg} /$ day); $\mathrm{MCF}=$ marker concentration in the animal feces $(\mathrm{kg} / \mathrm{kg})$, MCS = marker concentration in the supplement $(\mathrm{kg} / \mathrm{kg})$.

Calculation of dry matter intake was performed by using iNDF as the internal marker, throughthe following equation: DMI $(\mathrm{kg} /$ day $)=\{[(\mathrm{FE} \times \mathrm{CMF})-(\mathrm{CMS} \times \mathrm{DMSI})] /\} \mathrm{CIF}+$ DMSI, in which: $\mathrm{CMF}=$ concentration of marker in feces $(\mathrm{kg} / \mathrm{kg})$; CIF = concentration of indicator in the forage $(\mathrm{kg} / \mathrm{kg})$; DMSI = dry matter supplement intake (kg/day); $\mathrm{FE}=$ fecal excretion $(\mathrm{kg} /$ day $)$ and CMS = concentration of the marker in the supplement $(\mathrm{kg} / \mathrm{kg})$.

On the last day of the trial, in order to evaluate the nutritional parameters, at 2 p.m., spot urine collection $(10 \mathrm{~mL})$ from spontaneous urination was performed. Blood collections were done by jugular vein. After collection, urine samples were diluted in $40 \mathrm{~mL}$ of $\mathrm{H}_{2} \mathrm{SO}_{4}(0.036 \mathrm{~N})$ and frozen at $-20^{\circ} \mathrm{C}$. Blood samples were immediately centrifuged and plasma was frozen at $-20^{\circ} \mathrm{C}$.

Commercial kits (Human ${ }^{\circledR}$ ) were used to estimate the levels of urea in the plasma and in the urine (method Urease/GLDH), uric acid in the urine (Uricase method-PAD) and creatinine in urine (Jaffe method). The calculation of the daily urine volume was done by using the relationship between the daily excretion of creatinine (EC), adopting as reference the equation proposed by Chizzotti (2006), and its concentration in the "spot" samples: EC $(\mathrm{mg} / \mathrm{BW})=$ 32.27-0.01093 $\times$ BW, in which BW = body weight.

Analyses of allantoin in urine were performed by colorimetric method following the method of Fujihara et al. (1987). Total excretion of purine derivatives was calculated by the sum of quantities of allantoin and uric acid excreted in urine.

Absorbed purines (Y, mmol/day) were calculated from the excretion of purine derivatives ( $\mathrm{X}, \mathrm{mmol} / \mathrm{day}$ ) by using the equation: $\mathrm{Y}=\left(\mathrm{X}-0.385 \times \mathrm{BW}^{0.75}\right) / 0.85$, in which 0.85 = recovery of purines absorbed as purine derivatives; $0.385 \times \mathrm{BW}^{0.75}=$ endogenous contribution for excretion of purines (Verbic et al., 1990); BW = body weight.

Ruminal synthesis of nitrogen compounds (Z, g Nmic/day) was calculated in function of absorbed purines ( $\mathrm{Y}, \mathrm{mmol} / \mathrm{day})$, using the equation described by Chen and Gomes (1992), except for the purine $\mathrm{N}$ : Total $\mathrm{N}$ of bacteria 0.134 , according to Valadares et al. (1999): $\mathrm{Z}=70 \times \mathrm{Y} /(0.83 \times 0.134 \times 1000)$, in which $70=$ content of $\mathrm{N}$ purines $(\mathrm{mg} \mathrm{N} / \mathrm{mol}) ; 0.134$ for N purine: total $\mathrm{N}$ in bacteria, and $0.83=$ digestibility of bacterial purines.

A completely randomized design was adopted, and comparisons between treatment means were made using orthogonal contrasts (Table 2). Initial body weight was adopted as covariate. A ten-percent level of significance was used. All statistical procedures were performed by using the Statistical Analysis System (SAS).

Table 2 - Distribution of coefficients for orthogonal contrasts used in the decomposition of the sum of squares

\begin{tabular}{ccccccc}
\hline Contrast $^{1}$ & \multicolumn{2}{c}{$\begin{array}{c}\text { Study } \\
\text { factor }\end{array}$} & & \multicolumn{3}{c}{$\begin{array}{c}\text { Level of } \\
\text { supplementation }\end{array}$} \\
\cline { 2 - 3 } \cline { 6 - 7 } \cline { 6 - 7 } & Control & Nitrogen & salt & Low & Medium & High \\
\hline S & 4 & -1 & & -1 & -1 & -1 \\
NS & 0 & 3 & & -1 & -1 & -1 \\
L & 0 & 0 & & -1 & 0 & 1 \\
Q & 0 & 0 & & -1 & 2 & -1 \\
\hline
\end{tabular}

${ }_{1} \mathrm{~S}$ = effect of supplementation; NS = effect of supplementation with nitrogen sal on multiple supplementation; L and $\mathrm{Q}=$ linear and quadratic order effects in function of the level of supplementation used, respectively (Steel et al., 1997). 


\section{Results and Discussion}

Average availability of total dry matter (TDM) during the experimental period was $4.28 \mathrm{t} / \mathrm{ha}$. Average availability of pdDM during the experiment was 2.56t/ha.

Forage was considered of low quality, presenting crude protein average content of $6.64 \%$, below of $9 \%$ crude protein (CP), which optimizes the use of forage by cattle grazing (Figueiras et al., 2010), which can reduce animal performance because of the lower intake and energy use (Table 3).

Contents of urea + salt in the supplements controlled intake were at the amounts of 115, 173, 572, $1214 \mathrm{~g} / \mathrm{animal} /$ day for animals fed with nitrogen salt and for low, medium and high multiple levels of supplementation, respectively (Table 4). Supplement intake had a quadratic effect $(\mathrm{P}<0.10)$ in function of the level of urea + salt. Magalhães et al. (2006), when evaluating data from several experiments, found a non-linear effect for supplement intake in function of the level of urea and salt.

In the third experimental period, there was a decrease in average daily gain (ADG) (Figure 2), caused by the occurrence of heavy rainfall (Figure 1), which led to the emergence of tender shoots. The apparent decrease in weight of the animals may have been caused by the reduction in rumen fill due to the physiological occurrence of diarrhea caused by ingestion of forages with low fiber content and high water content.

After the rainy season, protein profile and content of forage consumed changed. Content of CP increased from 5.7 to $8.5 \%$ and the soluble protein from $30 \%$ to $35.5 \%$ CP (Figure 3). The regrowth of pasture resulted in a significant increase in nitrogen availability in the diet, most of it with rapid rumen degradability, allowing the maintenance of high levels of rumen nitrogen, although it did not guarantee adequate flow of true protein to the intestine (Poppi \& Mclennan, 1995). Thus, dietary deficiency of protein becomes a deficiency of metabolizable protein (Detmann et al., 2005).

Supplemented animals showed more reduced ADG after the rainy season than control animals (Figure 2), a fact that was caused in part by greater CP intake, particularly soluble protein, leading to excess of rumen ammonia and making necessary the expenditure of energy for excretion of this ammonia in the form of urea. The excess of circulating ammonia leads to a malfunction of brain tissue by energy deficit, causing discomfort to the animals, resulting in reduction in voluntary intake as a mechanism for reducing this symptom (Detmann et al., 2007).

Animals that received supplementation obtained a greater average daily gain (ADG) than control animals $(\mathrm{P}<0.10)$ (Table 4$)$. These results corroborate those obtained

Table 3 - Chemical composition of foods

\begin{tabular}{|c|c|c|c|c|c|c|}
\hline & \multirow[b]{2}{*}{ Control } & \multirow[b]{2}{*}{ Nitrogen salt } & \multicolumn{3}{|c|}{ Level of supplementation } & \multirow[t]{2}{*}{ B. decumbens ${ }^{1}$} \\
\hline & & & Low & Medium & High & \\
\hline Dry matter (\% natural matter) & 97.00 & 87.25 & 86.40 & 88.58 & 86.90 & $39.25 \pm 1.94$ \\
\hline Organic matter (\% dry matter) & - & 76.20 & 85.90 & 87.70 & 88.90 & $92.95 \pm 0.21$ \\
\hline Crude protein (\% dry matter) & - & 80.55 & 47.02 & 44.75 & 47.07 & $6.64 \pm 0.92$ \\
\hline Soluble protein (\% dry matter) & - & 93.84 & 84.50 & 45.65 & 35.03 & $31.92 \pm 2.22$ \\
\hline NDIN (\% total nitrogen $)^{2}$ & - & 1.57 & 3.58 & 3.98 & 4.33 & $35.51 \pm 3.66$ \\
\hline ADIN (\% total nitrogen $)^{3}$ & - & 0.41 & 1.00 & 2.95 & 3.08 & $11.78 \pm 0.58$ \\
\hline Ether extract (\% dry matter) & - & 2.10 & 2.20 & 2.33 & 2.32 & $1.78 \pm 0.12$ \\
\hline NDFap (\% dry matter) ${ }^{4}$ & - & 6.79 & 10.18 & 12.62 & 12.70 & $62.22 \pm 0.52$ \\
\hline Non-fibrous carbohydrates (\% dry matter) & - & 31.76 & 48.49 & 39.32 & 34.36 & $22.31 \pm 2.07$ \\
\hline Neutral detergent fiber (\% dry matter) & - & 3.66 & 3.07 & 4.45 & 4.64 & $30.82 \pm 0.65$ \\
\hline iNDF (\% dry matter) ${ }^{5}$ & - & 4.54 & 7.71 & 3.62 & 2.30 & $23.10 \pm 0.36$ \\
\hline Lignin (\% dry matter) & - & 1.97 & 2.06 & 2.20 & 2.17 & $5.70 \pm 0.15$ \\
\hline
\end{tabular}

Table 4 - Supplement intake and performance

\begin{tabular}{|c|c|c|c|c|c|c|c|c|c|c|}
\hline \multirow[b]{2}{*}{ Item } & \multirow[b]{2}{*}{ Control } & \multirow[b]{2}{*}{ Nitrogen salt } & \multicolumn{4}{|c|}{ Levels of supplementation } & \multicolumn{4}{|c|}{ Contrast $^{1,2}$} \\
\hline & & & Low & Medium & High & CV (\%) & $\mathrm{S}$ & NS & $\mathrm{L}$ & $\mathrm{Q}$ \\
\hline Supplement intake $(\mathrm{kg})^{3}$ & 0.040 & 0.115 & 0.173 & 0.572 & 1.214 & 38.6 & - & - & $* * *$ & $* * *(4)$ \\
\hline Final body weight & 211.9 & 216.8 & 209.8 & 221.7 & 229.2 & 2.71 & $* * *$ & ns & $* * *(5)$ & ns \\
\hline Total weight gain & 8.5 & 13.5 & 6.4 & 18.2 & 25.8 & 40.6 & $* * *$ & ns & $* * *$ & ns \\
\hline Average daily gain & 0.101 & 0.160 & 0.076 & 0.217 & 0.307 & 40.6 & $* * *$ & ns & $* * *(6)$ & ns \\
\hline
\end{tabular}

${ }^{1} \mathrm{~S}$ = non-supplemented versus supplemented; NS = nitrogen salt versus multiple supplementation; L and Q = linear and quadratic order effects relative to multiple supplementation levels, which involve only information related to levels of multiple supplement; ${ }^{2}(\mathrm{~ns}),\left({ }^{*}\right),\left({ }^{* *}\right)$ and $(* * *)=$ non-significant $(\mathrm{P}>0.10)$ and significant at the levels of $0.10,0.05$ and 0.01 of probability by the $\mathrm{F}$ test, respectively; ${ }^{3}$ regression in function of level of urea in the supplement; ${ }^{4} \hat{y}=1.873-0.107 \mathrm{X}+0.0014 \mathrm{X}^{2}$ $\left(r^{2}=0.79\right) ;{ }^{5} \hat{y}=209.66+13.91 X\left(r^{2}=0.99\right) ;{ }^{6} \hat{y}=0.061+0.211 X\left(r^{2}=0.98\right)$. 


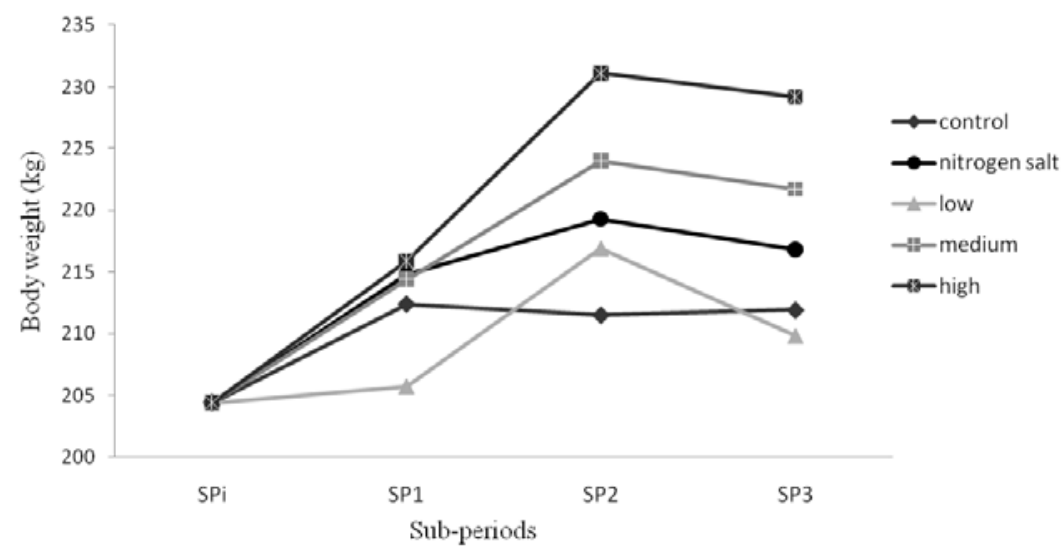

Figure 2 - Means of Minimum Square of initial body weight, body weight in the first subperiod (SP1), body weight in the second subperiod (SP2), and body weight in the third subperiod (SP3), adjusted for initial weight covariate.
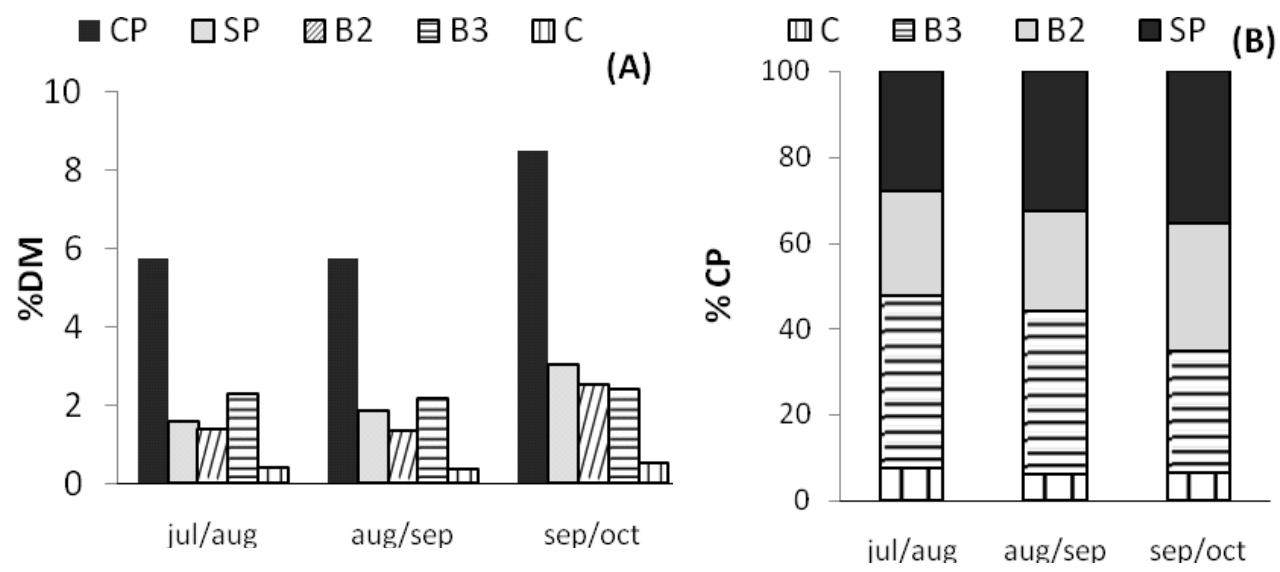

Figure 3 - Levels of crude protein (CP), proportions of soluble protein and B2, B3 and C fractions, expressed in function of dry matter (A); proportions of soluble protein (SP) and fractions B2, B3 and C, expressed in function of crude protein (B).

by Zervoudakis et al. (2002), who, working with beef heifers on pasture, fed them on supplements containing $40 \%$ CP ( $500 \mathrm{~g} /$ day) and observed greater weight gain compared with heifers which did not receive supplement. According to Hoover (1986), for low quality forage, limitations on the rate and extent of degradation can be attributed to a deficiency in the supply of essential nutrients such as nitrogen. In this experiment, the animals which received salt nitrogen showed greater weight gain than those which consumed only mineral, similar to results found by Vilela et al. (1981) and Ítavo et al. (2008), who found an increase in weight gain of animals with the addition of urea to the mineral salt during the dry season.

Overall, there were no differences $(\mathrm{P}>0.10)$ in ADG for animals that received nitrogen salt and those which received multiple supplementation (Table 4). Nitrogen salt presented high nitrogen concentration, enabling increase on CP ingestion even with low intake occurrence, increasing the supply of
RDP to fibrolytic bacteria, because in situations in which there are nitrogen limitations, this supply significantly increases the activity of this population (Russell et al., 1992). The lowest levels of multiple supplementation, for being supplied at low quantities, provided ADG of animals close to those found when nitrogen salt was supplied. However, the highest level of multiple supplementation provided a higher superiority in weight gain in relation to nitrogen salt. But, the average weight gain for the assessed levels of multiple supplements showed no difference from the value obtained by nitrogen salt.

The levels of protein supplementation presented a positive linear effect on the ADG of heifers with means of 76, 217 and $307 \mathrm{~g} /$ animal/day for the observed levels of protein supplementation of 173, 572 and $1214 \mathrm{~g} /$ animal/day for the low, medium and high levels of multiple supplementation (Table 4), evidencing that higher levels of supplementation increased ADG. 
In this study, there was a positive linear effect of multiple supplementation on ADG, with the supplementation until approximately $0.5 \%$ of $\mathrm{BW}$, corroborating the results from the literature, in which positive linear effects were found at levels higher than the ones used in this experiment, up to $0.8 \%$ PC (Euclides, 1998), and up to 1\% BW (Couto et al., 2009). However, the level where effect changes from liner to nonlinear depends on many factors like season, supplement composition and animal category.

The animals which consumed some type of supplement had higher intake of total dry matter $(\mathrm{TDM})(\mathrm{P}<0.10)$, dry matter from pasture (PDM) $(\mathrm{P}<0.10), \mathrm{CP}(\mathrm{P}<0.10)$, iNDF $(\mathrm{P}<0.10)$ and total digestible nutrients $(\mathrm{TDN})(\mathrm{P}<0.10)$ compared with control animals (Table 5).

Intake of TDM, OM and iNDF by animals under supplementation (Table 5) corroborate those obtained by Figueiras et al. (2010), who, working with animals on pasture during the dry season got higher values of TDM intake (22.65 g/kg BW ), PDM (22.53 g/kg BW) and iNDF $(4.63 \mathrm{~g} / \mathrm{kg} \mathrm{BW})$ when the dietary protein content raised up to $8.9 \% \mathrm{CP}$ in relation to intake of not supplemented animals (intakes of DM $=17.3 \mathrm{~g} / \mathrm{kg} \mathrm{BW}, \mathrm{PDM}=17.83 \mathrm{~g} / \mathrm{kg} \mathrm{BW}$; $\mathrm{iNDF}=3.58 \mathrm{~g} / \mathrm{kg} \mathrm{BW}$ ), in a diet with $7.4 \% \mathrm{CP}$.

Increase in the forage intake of supplemented animals is partially caused by the ability of protein supplementation to increase the activity of fibrolytic microorganisms when the pasture presents low protein content (Paulino et al., 2008).
Voluntary intake of dry matter by grazing animals is often limited due to the effect of rumen fill (Sampaio et al., 2009). High portion of this effect in the tropical forage has been attributed to the iNDF fraction. The greater intake of iNDF $(\mathrm{P}<0.10)$ by supplemented animals (Table 5$)$ is indicative of the rising rate of degradation of the fibrous components which reduces the permanence time of undegradable fractions in the rumen, accelerating rumen turnover, and consequently increases DM intake.

The levels of multiple supplements presented positive linear effect on $\mathrm{CP}$ intake $(\mathrm{P}<0.10)$. However, there was quadratic effect on the PDM intake $(\mathrm{P}<0.10), \operatorname{POM}(\mathrm{P}<0.10)$, NDF $(\mathrm{P}<0.10)$ and iNDF $(\mathrm{P}<0.10)$. Nevertheless, multiple supplementation increased these values $(\mathrm{P}<0.10)$ compared with control animals (Table 5). The increase in pasture intake may have been caused by an increase in rumen turnover, evidenced by greater intake of iNDF. The maximum intake of pasture was with $0.579 \mathrm{~kg}$ of multiple supplement per animal per day, in which, from this point, there was a decrease in pasture intake.

Multiple supplements had a protein-energy trait, with carbohydrate in its composition; the increase in the intake of such supplements by grazing animals consuming low quality forage enhances the effect of substitution (Souza et al., 2010), i.e., great consumption of supplement reduces pasture intake.

The excess of intake protein in high levels of multiple supplementation may limit the performance. Excessive

Table 5 - Least square means for nutrient intake

\begin{tabular}{|c|c|c|c|c|c|c|c|c|c|c|}
\hline & \multirow[b]{2}{*}{ Control } & \multirow[b]{2}{*}{ Nitrogen salt } & \multicolumn{3}{|c|}{ Levels of supplementation } & \multirow[b]{2}{*}{ CV (\%) } & \multicolumn{4}{|c|}{ Contrast $^{1,2}$} \\
\hline & & & Low & Medium & High & & $\mathrm{S}$ & NS & $\mathrm{L}$ & Q \\
\hline \multicolumn{11}{|c|}{ kg/day } \\
\hline Total dry matter & 3.55 & 5.04 & 5.08 & 5.71 & 5.88 & 18.8 & $* * *$ & ns & ns & ns \\
\hline Pasture dry matter & 3.55 & 4.94 & 4.74 & 4.78 & 4.20 & 17.4 & $* * *$ & ns & ns & ns \\
\hline NDFap $^{3}$ & 2.23 & 3.10 & 2.97 & 3.24 & 2.98 & 17.5 & $* * *$ & ns & ns & ns \\
\hline $\mathrm{dNDF}$ & 1.41 & 1.98 & 1.87 & 2.10 & 1.94 & 17.6 & $* * *$ & ns & ns & ns \\
\hline Crude protein & 0.20 & 0.36 & 0.43 & 0.70 & 1.03 & 28.0 & $* * *$ & $* * *$ & $* * *(6)$ & ns \\
\hline Ether extract & 0.096 & 0.091 & 0.104 & 0.146 & 0.152 & 18.8 & $* *$ & $* * *$ & $* * *(7)$ & ns \\
\hline Non-fibrous carbohydrates & 0.76 & 1.14 & 1.19 & 1.30 & 1.29 & 19.9 & $* * *$ & ns & ns & ns \\
\hline$\Delta \mathrm{MSP}^{4}$ & - & 1.29 & 1.19 & 1.23 & 0.65 & - & - & - & - & - \\
\hline $\operatorname{TPD}(\%)^{5}$ & 5.60 & 7.14 & 8.46 & 12.26 & 17.52 & - & - & - & - & - \\
\hline \multicolumn{11}{|c|}{$\mathrm{g} / \mathrm{kg} \mathrm{BW}$} \\
\hline Total dry matter & 17.21 & 23.05 & 23.04 & 28.13 & 25.83 & 16.3 & $* * *$ & ns & ns & ns \\
\hline Pasture dry matter & 17.21 & 22.56 & 21.50 & 23.53 & 18.53 & 15.8 & $* * *$ & ns & ns & $*(8)$ \\
\hline Total organic matter & 15.90 & 21.20 & 20.92 & 25.90 & 23.43 & 16.2 & $* * *$ & ns & ns & ns \\
\hline Pasture organic matter & 15.90 & 20.82 & 19.60 & 21.85 & 16.94 & 15.8 & $* * *$ & ns & ns & $*(9)$ \\
\hline $\mathrm{NDFap}^{3}$ & 10.80 & 14.15 & 13.46 & 15.95 & 13.15 & 15.2 & $* * *$ & ns & ns & $*(10)$ \\
\hline $\begin{array}{l}\text { Indigestible neutral } \\
\text { detergent fiber }\end{array}$ & 4.09 & 5.32 & 4.88 & 5.63 & 4.35 & 15.7 & $* * *$ & ns & ns & $* *(11)$ \\
\hline$\underline{\text { Total digestible nutrients }}$ & 8.61 & 12.01 & 12.08 & 15.95 & 15.10 & 17.7 & $* * *$ & $* *$ & $*(12)$ & ns \\
\hline
\end{tabular}


protein intake causes the body to spend energy to excrete excess nitrogen, which increases caloric increment and the animal may present difficulties to remove the heat produced. In conditions where there is difficulty in heat loss, DM intake is reduced (Neiva et al., 2004).

Similarly to pasture conditions, rumen fill of insoluble fiber fraction determines intake capacity (Sampaio et al., 2009). Although the substitution of pasture intake by supplementation has intensified at the highest levels, showing a quadratic effect, the value of TDN showed positive linear effect $(\mathrm{P}<0.10)$. Thus, even when the use of pasture decreased, the total amount of energy obtained by the animal was increasing. When the slope becomes zero or negative, the supplement does not add energy to the system; it may even cause damage to the rumen, reducing the amount of dietary energy.

Supplemented animals presented higher dry matter digestibility $(\mathrm{P}<0.10)$, organic matter $(\mathrm{P}<0.10)$, non-fibrous carbohydrates $(\mathrm{P}<0.10), \mathrm{CP}(\mathrm{P}<0.10)$ and higher value of TDN $(\mathrm{P}<0.10)$ compared with control animals, although differences in NDF digestibility did not occur $(\mathrm{P}>0.10)$ (Table 6).

Figueiras et al. (2010), when working with animals on pasture during the dry season, found greater digestibility of DM and NDFap and TDN for animals which received protein supplementation in relation to animals consuming only forage. Acedo et al. (2007), during the dry season, found no differences among NDFap digestibility between animals fed on multiple supplements or without supplementation.

Critical analysis of the NDFap digestibility alone is not a good indicator of the use of fiber. Although the digestibility of NDFap was not affected ( $\mathrm{P}>0.10)$ by supplementation, consumption of NDFap increased $(\mathrm{P}<0.10)$, as a response of the higher rate of NDF degradation, evidenced by greater $(\mathrm{P}<0$ 10) intake of digested NDF (DNDF) (Table 5). The animals of the control may have obtained high value of the
NDFap digestibility by the low rumen turnover, evidenced by lower consumption of iNDF (Table 5), thus, digestibility may have been more affected by the longer permanence of the substrate in the rumen than by the rate of fiber degradation by ruminal bacteria.

The dynamics of rumen degradation of NDF is a secondorder dynamic process (Detmann et al., 2009), i.e., at the deficiency of nitrogen compounds, the degradation would be limited not only by the intrinsic characteristics of the substrate, but also by the deficiency of microbial enzymatic systems (Paulino et al., 2006). Thus, the correction of these deficiencies may increase the amount of energy obtained from fiber and increase the availability of energy for the animals.

Animals that consumed multiple supplements presented greater DM digestibility $(\mathrm{P}<0.10), \mathrm{OM}(\mathrm{P}<0.10)$ and $\mathrm{CP}$ $(\mathrm{P}<0.10)$ and TDN value higher $(\mathrm{P}<0.10)$ than animals which consumed nitrogen salt (Table 6).

Levels of multiple supplementation presented a positive linear effect $(\mathrm{P}<0.10)$ to digestibility of DM, CP, NDFap and NFC, and to the value of TDN.

There was higher $(\mathrm{P}<0.10)$ microbial nitrogen synthesis (Nmic) in supplemented animals compared with control animals (Table 7). The highest Nmic production, in response to additional nitrogen supply, indicates that the protein level of forage was insufficient for the supply of nitrogen compounds to optimize microbial growth (Table 7).

The levels of protein supplementation showed a positive linear effect $(\mathrm{P}<0.10)$ on Nmic production. The largest consumption of supplement provided greater availability of nitrogen and energy readily available for microbial assimilation. For every $1 \mathrm{~kg}$ of protein supplement ingested, there was a $60 \%$ increase in microbial protein synthesis compared with control.

Nascimento et al. (2009), when working with crossbred steers supplemented with $0.4 \% \mathrm{BW}(30 \% \mathrm{CP})$ during the

Table 6 - Least square means for apparent digestibility

\begin{tabular}{|c|c|c|c|c|c|c|c|c|c|c|}
\hline & \multirow[b]{2}{*}{ Control } & \multirow[b]{2}{*}{ Nitrogen salt } & \multicolumn{3}{|c|}{ Levels of supplementation } & \multirow[b]{2}{*}{ CV (\%) } & \multicolumn{4}{|c|}{ Contrast $^{1,2}$} \\
\hline & & & Low & Medium & High & & $\mathrm{S}$ & NS & $\mathrm{L}$ & Q \\
\hline Dry matter & 49.1 & 52.6 & 52.0 & 54.5 & 57.1 & 4.1 & $* * *$ & $* *$ & $* * *(5)$ & ns \\
\hline Organic matter & 52.7 & 54.5 & 54.7 & 58.0 & 60.5 & 3.5 & $* * *$ & $* * *$ & $* * *(6)$ & ns \\
\hline Crude protein & 26.0 & 47.4 & 54.3 & 66.8 & 73.4 & 6.3 & $* * *$ & $* * *$ & $* * *(7)$ & ns \\
\hline Ether extract ${ }^{3}$ & 48.9 & 39.6 & 34.5 & 53.23 & 45.04 & 16.8 & $* * *$ & ns & $* *$ & $*(8)$ \\
\hline NDFap $^{4}$ & 63.6 & 63.7 & 63.1 & 64.9 & 65.0 & 3.1 & ns & ns & $*(9)$ & ns \\
\hline Non-fibrous carbohydrates & 29.8 & 38.3 & 42.3 & 42.4 & 47.8 & 12.9 & $* * *$ & $* * *$ & $*(10)$ & ns \\
\hline Total digestible nutrients & 49.9 & 51.1 & 51.4 & 56.7 & 57.8 & 2.9 & $* * *$ & $* * *$ & $*(11)$ & ns \\
\hline
\end{tabular}

$1 \mathrm{~S}$ = non-supplemented versus supplemented; NS = nitrogen salt versus multiple supplementation; L and Q = linear and quadratic order effects on multiple supplementation levels, which involves only information from levels of multiple supplement; ${ }^{2} /(\mathrm{ns}),(*),(* *)$ and $(* * *)=$ non-significant $(\mathrm{P}>0.10)$ and significant at the levels of $0.10,0.05$ and 0.01 of probability by the F test, respectively; ${ }^{3}$ calculated by equation proposed by Detmann et al. (2006); ${ }^{4}$ neutral detergent fiber corrected for ash and protein; ${ }^{5} \hat{y}=51.32+4.81 \mathrm{X}\left(\mathrm{r}^{2}=0.95\right) ;{ }^{6} \hat{\mathrm{y}}=54.17+5.39 \mathrm{X}\left(\mathrm{r}^{2}=0.96\right) ;{ }^{7} \hat{\mathrm{y}}=53.11+17.54 \mathrm{X}\left(\mathrm{r}^{2}=0.98\right) ;{ }^{8} \hat{\mathrm{y}}=39.34+6.93 \mathrm{X}\left(\mathrm{r}^{2}=0.46\right) ;{ }^{9} \hat{\mathrm{y}}=63.2+1.65 \mathrm{X}$ $\left(\mathrm{r}^{2}=0.73\right) ;{ }^{10} \hat{y}=37.26+6.38 \mathrm{X}\left(\mathrm{r}^{2}=0.79\right) ;{ }^{11} \hat{\mathrm{y}}=52.33+5.34 \mathrm{X}\left(\mathrm{r}^{2}=0.95\right)$. 
Table 7 - Least square mean for ruminal parameters

\begin{tabular}{|c|c|c|c|c|c|c|c|c|c|c|}
\hline \multirow[b]{2}{*}{ Item } & \multirow[b]{2}{*}{ Control } & \multirow[b]{2}{*}{ Nitrogen salt } & \multicolumn{3}{|c|}{ Levels of supplementation } & \multirow[b]{2}{*}{ CV (\%) } & \multicolumn{4}{|c|}{ Contrast $^{1,2}$} \\
\hline & & & Low & Medium & High & & $\mathrm{S}$ & NS & $\mathrm{L}$ & $\mathrm{Q}$ \\
\hline Microbial nitrogen (g/day) & 43.5 & 56.2 & 51.4 & 62.2 & 79.6 & 12.3 & $* * *$ & $* *$ & $* * *(6)$ & ns \\
\hline Microbial efficiency ${ }^{3}$ & 154.5 & 137.9 & 129.6 & 125.2 & 136.6 & 17.0 & $* *$ & ns & ns & ns \\
\hline Serum urea nitrogen (mg/dL) & 7.9 & 10.5 & 10.1 & 19.4 & 27.0 & 25.1 & $* * *$ & $* * *$ & $* * *(7)$ & ns \\
\hline Total urinary nitrogen (g/day) & 20.60 & 40.71 & 34.9 & 54.6 & 84.8 & 26.2 & $* * *$ & $* * *$ & $* * *(8)$ & ns \\
\hline Nitrogen balance ${ }^{4}$ & 0.648 & 0.675 & 0.517 & 0.430 & 0.531 & 21.3 & $*$ & $* * *$ & ns & ns \\
\hline Comparative microbial nitrogen ${ }^{5}$ & 1.37 & 0.99 & 0.78 & 0.53 & 0.50 & 17.4 & $* * *$ & $* * *$ & $* * *(9)$ & ns \\
\hline
\end{tabular}

${ }^{1} \mathrm{~S}$ = non-supplemented versus supplemented; NS = nitrogen salt versus multiple supplementation; L and Q = linear and quadratic order effects relative to multiple supplementation levels, which involves only information from levels of multiple supplements; ${ }^{2}$ (ns), $(*),(* *)$ and $(* * *)=$ non-significant $(\mathrm{P}>0.10)$ and significant at the levels of $0.10,0.05$ and 0.01 of probability by the $\mathrm{F}$ test, respectively; ${ }^{3} \mathrm{~g}$ microbial CP/ $\mathrm{kg} \mathrm{TDN} ;{ }^{4} \mathrm{~g}$ of excreted nitrogen $/ \mathrm{g}$ of ingested nitrogen; ${ }^{5}$ production of microbial $\mathrm{N}$ per ingested $\mathrm{N} ;{ }^{6} \hat{y}=45.67+26.74 \mathrm{X}\left(\mathrm{r}^{2}=0.98\right) ;{ }^{7} \hat{y}=7.98+16.28 \mathrm{X}\left(\mathrm{r}^{2}=0.97\right) ;{ }^{8} \hat{y}=23.96+49.38 \mathrm{X}\left(\mathrm{r}^{2}=0.74\right) ;{ }^{9} \hat{y}=0.787-0.294 \mathrm{X}\left(\mathrm{r}^{2}=0.94\right)$.

dry-rainy transition period, observed that the supplemented animals obtained Nmic production 34.4\% higher than the control animals. A similar behavior was observed in this study, in which for the estimated level of multiple supplement (45\% CP) OF $0.4 \%$ BW (800 g/day), 48\% of production superiority was found in Nmic production when compared to control animals.

The control animals presented higher microbial efficiency $(\mathrm{P}<0.10)$ compared with animals which received multiple supplementation (Table 7). The highest microbial efficiency of the control animals was not due to the highest microbial production but to the lower intake of TDN, instead (Table 5), since microbial efficiency is the ratio between microbial CP (g) and TDN intake (kg). When dietary protein content was corrected, microbial efficiency tended to present fixed value, with an increase in Nmic proportional to the increased consumption of TDN. Supplemented animals had microbial efficiency of $132 \mathrm{~g} / \mathrm{kg}$ TDN, a value close to $130 \mathrm{~g} / \mathrm{kg}$ of TDN recommended by the NRC (1996).

Control animals showed Nmic production related to dietary nitrogen intake (NmicR) above the value 1 (Table 7), indicating a sharp protein deficit in the diet and a possible mobilization of body nitrogen to keep microbial activity in the rumen.

Animals that received some type of supplement had higher serum urea nitrogen concentration (SUN) $(\mathrm{P}<0.10)$. Control animals showed an average value of $7.9 \mathrm{mg} / \mathrm{dL}$ and supplemented animals had an average of $16.75 \mathrm{mg} / \mathrm{dL}$ due to higher CP intake of these animals, once the concentration of SUN is positively correlated with intake of nitrogen.

The levels of protein supplementation presented a positive linear effect $(\mathrm{P}<0.10)$ on SUN. Multiple supplement intake from $430 \mathrm{~g} / \mathrm{day}$, enabled NUS values to exceed the range of 13-15 mg/dL, indicating a probable loss of protein (Valadares et al., 1997).

Although the total amount of nitrogen excreted in the urine rose with the increase in $\mathrm{CP}$ intake, nitrogen balance (BN) became more favorable (Table 7). Animals fed on multiple supplementation presented lower $(\mathrm{P}<0.10)$ (better)
NB compared with control animals or ones which received nitrogen salt. The increase in CP intake followed by fast degradation carbohydrate (multiple supplement) caused an increase in microbial assimilation of nitrogen compounds in the rumen in proportion to consumed CP.

\section{Conclusions}

Energy-mineral-protein supplementation (multiple supplementation or nitrogen salt) has a positive effect on nutritional traits with positive responses on performance of grazing beef cattle.

\section{References}

ACEDO, T.S.; PAULinO, M.F.; DETMANN, E. et al. Níveis de uréia em suplementos para terminação de bovinos em pastejo durante a época seca. Acta Scientiarum.Animal Sciences, v.29, n.3, p.301-308, 2007.

CASALI, A.O.; DETMANN, E.; VALADARES FILHO, S.C. et al. Influência do tempo de incubação e do tamanho de partículas sobre os teores de compostos indigestíveis em alimentos e fezes bovinas obtidos por procedimentos in situ. Revista Brasileira de Zootecnia, v.37, n.2, p.335-342, 2008.

CHEN, X.B.; GOMES, M.J. Estimation of microbial protein supply to sheep and cattle based on urinary excretion of purine derivatives - an overview of technical details (Occasional publication). Bucksburnd, Aberdeen: Rowett Research Institute, 1992. 21p. (International Feed Resources Unit).

CHIZZOTTI, M.L.; VALADARES FILHO, S.C.; VALADARES, R.F.D. et al. Consumo, digestibilidade e excreção de uréia e derivados de purinas em novilhas de diferentes pesos. Revista Brasileira de Zootecnia, v.35, n.4, p.1813-1821, 2006.

COUTO, V.R.M.; PAULINO, M.F.; VALENTE, E.E.L. et al. Níveis de suplementação para novilhas de corte durante a estação das águas. In: REUNIÃO ANUAL DA SOCIEDADE BRASILEIRA DE ZOOTECNIA, 46., Maringá. Anais... Maringá: SBZ, 2009. (CD-ROM).

DETMANN, E.; PAUlinO, M.F.; CECON, P.R. et al. Níveis de proteína em suplementos para terminação de bovinos em pastejo durante o período de transição seca/águas: consumo voluntário e transito de partículas. Revista Brasileira de Zootecnia v.34, n.4, p.1371-1379, 2005.

DETMANN, E.; PAULINO, M.F.; VALADARES FILHO, S.C. et al. Fatores controladores de consumo em suplementos múltiplos fornecidos ad libitum para bovinos manejados a pasto. Caderno Técnico de Veterinária e Zootecnia, v.55, p.73-93, 2007. 
DETMANN, E.; PAULINO, M.F.; MANTOVANi, H.C. et al. Parameterization of ruminal fibre degradation in low-quality tropical forage using Michaelis-Menten kinetics. Livestock Science, v.126, p.136-146, 2009.

DETMANN, E. AND VALADARES FILHO, S.C. On the estimation of non-fibrous carbohydrates in feeds and diets, Arquivo Brasileiro de Medicina Veterinária e Zootecnia, v.62, p. 980-984, 2010.

EL-SHAZLY, K.; DEHORITY, B.A.; JOHSON, R.R. Effect of starch on the digestion of cellulose in vitro and in vivo by rumen microorganism. Journal of Animal Science, v.20, p.268-273, 1961.

EUCLIDES, V.P.B.; EUCLIDES FILHO, K.; ARRUDA, Z.J. et al. Desempenho de novilhos em pastagem de Brachiaria decumbens submetidos a diferentes regimes alimentares. Revista Brasileira de Zootecnia, v.27, n.2, p.246-254, 1998.

FIGUEIRAS, J.F.; DETMANN, E.; PAULINO, M.F. et al. Intake and digestibility in cattle under grazing supplemented with nitrogenous compounds during dry season, Revista Brasileira de Zootecnia, v.39, n.6, p.1303-1312, 2010.

FIGUEIREDO, D.M.; OLIVEIRA, A.S.; SALES, M.F.L. et al. Análise econômica de quatro estratégias de suplementação para recria e engorda de bovinos em sistema pasto-suplemento. Revista Brasileira de Zootecnia, v.36, n.5, p.1443-1453, 2007.

FUJIHARA, T.; ØRSKOV, E.R.; REEDS, P.J. et al. The effect of protein infusion on urinary excretion of purine derivatives in ruminants nourished by intragastric nutrition. The Journal of Agricultural Science, v.109, n.1, p.7-12, 1987.

HOOVER, W.H. Chemical factors involved in ruminal fiber digestion. Journal of Dairy Science, v.69, n.10, p.2755-2766, 1986.

LICITRA, G.; HERNANDEZ, T.M.; VAN SOEST, P.J. Standardization of procedures for nitrogen fractionation of ruminant feeds. Animal Feed Science and Technology, v.57, n.4, p.347-358, 1996.

MAGALHÃES, K.A.; DETMANN, E.; VALADARES FILHO, S.C. et al. Efeitos dos níveis de sal e uréia em suplementos múltiplos para bovinos em pastejo: consumo. In: REUNIÃO ANUAL DA SOCIEDADE BRASILEIRA DE ZOOTECNIA, 43., Goiânia. Anais... Goiânia: SBZ, 2006. (CD-ROM).

MALAFAIA, P.A.M.; VIEIRA, R.A.M. Técnicas de determinação dos compostos nitrogenados em alimentos para ruminantes. In: DIGESTIBILIDADE EM RUMINANTES, 1997, Lavras. Anais... Lavras: FAEP, 1997. p.29-54.

MERTENS, D.R. Gravimetric determination of amylase treated neutral detergent fiber in feeds with refluxing in beakers or crucibles: collaborative study. Journal of AOAC International, v.85, n.6, p.1212-1240, 2002.

NASCIMENTO, M.L.; PAULINO, DETMANN, E. et al. Fontes de energia em suplementos múltiplos para recria de novilhos mestiços em pastejo durante o período de transição seca/águas: desempenho produtivo e características nutricionais. Revista Brasileira de Zootecnia, v.38, n.6, p.1121-1132, 2009.

NATIONAL RESEARCH COUNCIL - NRC. Nutrient requirements of beef cattle. 7.ed. Washington, D.C.: National Academy, 1996. 242p.

NEIVA, J.N.M.; TEIXEIRA, M.; TURCO, S.H.N. et al. Efeito do estresse climático sobre os parâmetros produtivos e fisiológicos de ovinos Santa Inês mantidos em confinamento na Região Litorânea do Nordeste do Brasil. Revista Brasileira de Zootecnia, v.33, n.3, p.668-678, 2004.

PAULINO, M.F.; DETMANN, E.; ZERVOUDAKIS, J.T. Suplementos múltiplos para recria e engorda de bovinos em pastagens. In: SIMPÓSIO DE PRODUÇÃO DE GADO DE CORTE, 2., 2001, Viçosa, MG. Anais... Viçosa, MG: SIMCORTE, 2001. p.187-233.

PAULINO, M.F.; DETMANN, E.; VALADARES FILHO, S.C. Suplementação animal em pasto: energética ou protéica? In:
SIMPÓSIO SOBRE MANEJO ESTRATÉGICO DA PASTAGEM, 3., 2006, Viçosa, MG. Anais... Viçosa, MG: SIMFOR, 2006. p.359-392.

PAULINO, M.F.; DETMANN, E.; VALENTE, E.E.L. et al. Nutrição de bovinos em pastejo. In: SIMPÓSIO SOBRE MANEJO ESTRATÉGICO DA PASTAGEM, 4., 2008, Viçosa, MG. Anais... Viçosa, MG: SIMFOR, 2008. p.131-169.

POPPI, D.P.; McLENNAN, S.R. Protein and energy utilization by ruminants at pasture. Journal of Animal Science, v.73, p.278-290, 1995.

RUSSELL, J.B.; O'CONNOR, J.D.; FOX D.G. et al. A net carbohydrate and protein system for evaluating cattle diets: I. Ruminal fermentation. Journal of Animal Science, v.70, n.11, p.3551-3561, 1992.

SAMPAIO, C.B.; DETMANN, E.; LAZZARINI, I. et al. Dinâmica ruminal da fibra em detergente neutro em bovinos alimentados com forragem tropical de baixa qualidade e suplemento com compostos nitrogenados. Revista Brasileira de Zootecnia, v.38, n.3, p.560-569, 2009.

SHORT, F.J.; GORTON, P.; WISEMAN, J. et al. Determination of titanium dioxide added as an inert marker in chicken digestibily studes. Animal Feed and Technology, v.59, n.4, p.215-221, 1996.

SILVA, D.J.; QUEIROZ, A.C. Análise de alimentos: métodos químicos e biológicos. 3.ed. Viçosa, MG: UFV, Imprensa Universitária, 2002. 235p.

SOUZA, M.A., DETMANN, E., PAUlino, M.F. et al. Intake, digestibility and rumen dynamics of neutral detergent fiber in cattle fed low-quality tropical forage and supplemented with nitrogen and/or starch. Tropical Animal Health and Production, v.42, p.1299-1310, 2010.

SteEL, R.G.; TORRIE, J.H.; DICKEY, D.A. Principles and procedures of statistics. A biometrical approach. New York: McGraw-Hill Co., 1997. 666p.

VALADARES, R.F.D.; GONÇALVES, L.C.; SAMPAIO, I.B. et al. Níveis de proteína em dietas de bovino. 4. Concentrações de amônia ruminal e uréia plasmática e excreções de uréia e creatinina. Revista Brasileira de Zootecnia, v.26, n.6, p.1270-1278, 1997.

VALADARES, R.F.D.; BRODERICK, G.A.; VALADARES FILHO, S.C. et al. Effect of replacing alfalfa silage with high moisture corn on ruminal protein synthesis estimated from excretion of total purine derivatives. Journal of Animal Science, v.82, n.11, p.2686-2696, 1999.

VAN SOEST, P.J.; ROBERTSON, J.B. Analysis of forages and fibrous foods. Ithaca: Cornell University, 1985. 202p.

VERBIC, J.; CHEN, X.B.; MACLEOD, N.A. et al. Excretion of purine derivatives by ruminants. Effects of microbial nucleic acid infusion on purine derivative excretion by steers. Journal of Agricultural Science, v.114, n.3, p.243-248, 1990.

VILELA, H.; DEMTCHENKO, A.; VILELA, D. et al. Efeitos da adição de uréia à mistura mineral sobre o ganho de peso de bezerros desmamados, em pastejo, durante o período de seca. In: REUNIÃO ANUAL DA SOCIEDADE BRASILEIRA DE ZOOTECNIA, 18., 1981, Goiânia. Anais... Goiânia: SBZ, 1981. p.353.

WILLIANS, C.H.; DAVID, D.J.; IISMA, O. The determination of chromic oxide in faeces samples by atomic absorption spectrophotometry. Journal of Agricultural Science, v.59, v.3, p.381-385, 1962.

ZERVOUDAKIS, J.T.; PAULINO, M.F.; DETMANN, E. et al. Desempenho de novilhas mestiças e parâmetros ruminais em novilhos, suplementados durante o período das águas. Revista Brasileira de Zootecnia, v.3, n.2, p.1050-1058, 2002. 